\title{
The Interaction Between Conventional Monetary Policy and Financial Stability: Chile, Colombia, Japan, Portugal and the UK
}

\section{Zoë Venter ${ }^{1}[0$}

Published online: 3 August 2020

(c) Association for Comparative Economic Studies 2020

\begin{abstract}
The relationship between monetary policy and financial stability has gained importance in recent years as Central Bank policy rates neared the zero-lower bound. We use an SVAR model to study the impact of monetary policy shocks on three proxies for financial stability as well as a proxy for economic growth. Monetary policy is represented by policy rates for the emerging market economies and shadow rates for the advanced economies in our paper. Our main results show that monetary policy may be used to correct asset mispricing, to control fluctuations in the real business cycle and also to tame credit cycles in the majority of cases. Our results also show that for the majority of cases, in line with conventional wisdom, local currencies appreciate following a positive monetary policy shock. Monetary policy intervention may indeed be successful in contributing to or achieving financial stability. The results, however, show that monetary policy may not have the ability to maintain or re-establish financial stability in all cases. Alternative policy choices such as macroprudential policy tool frameworks which are aimed at targeting the financial system as a whole may be implemented as a means of fortifying the economy.
\end{abstract}

Keywords Monetary policy · Financial stability $\cdot$ Structural vector autoregressive model

JEL Classification E52 $\cdot$ F42 $\cdot$ F34 $\cdot$ F55

Zoë Venter

zoeventer14@phd.iseg.ulisboa.pt

1 ISEG, Lisbon School of Economics and Management, Universidade de Lisboa, R. Miguel Lúpi, 20, 1249-078 Lisbon, Portugal 


\section{Introduction}

The relationship between monetary policy and financial stability became an important topic in the aftermath of the 2008-2009 global financial crisis (GFC) as Central Banks lowered their policy rates in an effort to revive the economy and the zerolower bound loomed. ${ }^{1}$ Traditionally, price stability has been the main objective of Central Banks and therefore of monetary policy. However, the crisis emphasized the need to implement alternative measures and to expand the scope of monetary policy to include a focus on the maintenance of financial stability while maintaining the primary objective of achieving price stability. Kryvstov et al. (2015) discuss the relationship between financial and macroeconomic conditions. They note that financial stability conditions are an important part of monetary policy implementation as financial stability is a precondition for a well-functioning financial system.

The purpose of this paper is to study the impact of monetary policy shocks on financial stability for the cases of Chile, Colombia, Japan, Portugal and the UK. Monetary policy influences the amount of money in circulation in the economy as well as the borrowing cost of money. The countries chosen have autonomous, inflation-targeting Central Banks, which provides the opportunity for more independent monetary policy decisions. In the case of Colombia and Chile, this combined with a lack of empirical studies due to limited data availability makes for an interesting case study. The UK dilemma following a tumultuous period of Brexit negotiations and uncertainty topped off by growing economic and social uncertainty and loss in the midst of the current COVID-19 pandemic and Japan's unending battle with deflation and sluggish growth justifies the study of the UK and Japan. Lastly, although Portuguese monetary policy is determined by the objectives of the European Central Bank, the effect on credit growth in Portugal is noteworthy considering Portugal's recent economic recovery following a bailout from the troika formed by the European Commission, European Central Bank and the International Monetary Fund. The potential impact of the current global pandemic on the newly recovered Portuguese economy solidifies the need to study the case of Portugal. The five countries are looked at on a case-by-case basis with the impact of monetary policy shocks on financial stability being studied for each individual country case.

A decade after the GFC, financial stability and the effective implementation of monetary policy remains a priority for many Central Banks. Studying the relationship between monetary policy and financial stability, in particular, the effect on different areas of potential vulnerability may play an important role in future targeted policy decisions. A number of structural vector autoregressive (SVAR) analyses have been conducted on the US Economy as well as other advanced economies. However, due to shorter time series caused by limited data availability as well as structural reforms in Latin American countries, SVARs have not been used frequently in econometric studies. SVAR models based on the VAR approach suggested by Sims (1980) have been used frequently in Japan, Portugal and the UK with

\footnotetext{
1 Advanced economies had limited options to further reduce policy rates and, hence, employed unconventional monetary policy tools such as quantitative easing.
} 
four available examples being Nakahira (2009), Afonso and Sousa (2011, 2012) and Elbourne (2008), respectively. In this paper, an SVAR is employed and impulse response functions are used in an effort to test the impact of monetary policy on financial stability. As in Cocriş and Nucu (2013), the impact of short-term interest rates on three proxies for financial stability, namely credit growth, stock prices and the exchange rate, is studied. Industrial production is included as a proxy for the real sector and hence, for economic growth. In line with Cocris and Nucu (2013), policy rates are used to represent monetary policy choices in emerging economies. Shadow rates are used to represent monetary policy intervention in advanced economies.

Our main results show that monetary policy may be used to correct asset mispricing due to the inverse relationship between monetary policy intervention and the stock market index for four of the five cases, namely the cases of Colombia, Japan, Portugal and the UK. Conventional wisdom ${ }^{2}$ suggest that contractionary monetary policy would result in a currency appreciation in countries with a floating exchange rate regime as foreign investment is attracted. The results show that the exchange rate appreciates following a monetary policy shock for the cases of Chile, Japan and Portugal while the currency depreciates for the cases of Colombia and the UK. The currency depreciation in the case of Colombia could be attributed to the country's reliance on exports as Colombia relies heavily on commodity exportation while, in the case of the UK, this depreciation is attributed to uncertainty in the local market.

The results also show that monetary policy may be used to limit fluctuations in the real business cycle as can be seen by the inverse relationship between the industrial production index and monetary policy intervention in the majority of cases, namely, for the cases of Colombia, Japan and Portugal. Credit growth also has an inverse relationship with monetary policy intervention in the cases of Chile and the UK. Ergo, monetary policy may be used to tame credit cycles. In the cases of Colombia, Japan and Portugal, credit moves in the same direction as monetary policy intervention. Thus, positive monetary policy shock results in an increase in credit. The results show that monetary policy intervention as represented by policy rates and shadow rates may indeed be able to contribute to financial stability. The results show that monetary policy may not have the ability to maintain or re-establish financial stability in all cases. Alternative policy choices such as macroprudential policy tools aimed at targeting the financial system as a whole may be useful to reinforce the monetary policy framework.

The rest of the paper is as follows: Literature Review" section surveys existing literature; "Methodology and Data" section discusses the methodology and the data used; "Empirical Results" section discusses the empirical results; and "Conclusion" section concludes.

\footnotetext{
2 See Inoue and Rossi (2019), Clarida and Galí (1994), Eichenbaum and Evans (1995) and Faust and Rogers (2003).
} 


\section{Literature Review}

Financial instability is defined as a situation in which the economic performance of an economy is potentially affected by price fluctuations of financial assets (Crockett 1997). In this paper, three proxies for financial stability are included, the first being credit growth which is looked at in existing literature. For example, Jiménez et al. (2012) look at the impact of monetary policy on the supply of credit. They show that tighter monetary policy and weaker economic conditions substantially reduce loan granting, in particular loan granting by banks with lower capital or liquidity ratios. In this paper, we find that tighter monetary policy results in reduced credit growth in Chile and the UK and increased credit growth in Colombia, Japan and Portugal. Jiménez et al. (2012) also note that the GFC showed that the use of monetary policy rates as a means of supporting credit growth seems advisable. Further, Allen and Gale (2007), Schularick and Taylor (2012), Gourinchas and Obstfeld (2012) and Borio (2014) find that credit growth fluctuations are a common forerunner of financial crises. ${ }^{3}$ Also, Jordà et al. (2013) show that excess credit growth in the period prior to a peak is usually associated with a more severe recession and Bernanke and Lown (1991) and Calvo and Reinhart (2000) note that crises are often accompanied by bank credit crunches and halting foreign capital flows. Given the importance of credit growth as a harbinger of crises as well as an indicator of the magnitude of crises, the study of the relationship between credit growth and monetary policy intervention as represented by policy rates for emerging economies and shadow rates for advanced economies is of importance.

Our second proxy for financial stability is the exchange rate, the inclusion of which is substantiated by existing literature. For example, exchange rate depreciation is used as a proxy for financial vulnerability in both Eichengreen and Gupta (2015) and Park et al. (2016). Further, Eichenbaum and Evans (1995) make use of a VAR analysis to investigate the effect of shocks (in monetary policy) on exchange rates in the USA and find that contractionary monetary policy results in a long-lasting appreciation in the exchange rate. Our results show that tighter monetary policy results in an appreciation of the local currency in Chile, Japan and Portugal. The local currency in the UK and Colombia, however, depreciates. Dhrymes (1997) look at more economically compatible SVAR models, they find that foreign interest rates and the real exchange rate are determinants of real output. Lastly, Cavallari (2001) finds that monetary shocks have no effect on real variables in the long run when considering a SVAR. In contrast, Lee and Chinn (2002) extended this model to include exchange rate data and found that monetary policy does indeed influence exchange rates.

Our final proxy for financial stability is the growth in the stock market which is looked at in earlier literature. Granville and Mallick (2009) use stock prices, exchange rates and loan-to-deposit ratios as proxies for financial stability and define

\footnotetext{
3 These results are in line with Jordà et al. (2011), Drehmann et al. (2011) and Schularick and Taylor (2012).
} 
financial stability in terms of changes in stock prices. ${ }^{4}$ Asiriyan et al. (2019) consider monetary policy in a bubbly world where low interest rates result in frequent booms and busts in asset prices. Both monetary policy and bubbles have expansionary effects on the economy with bubbles having both an overhang effect and a wealth effect. ${ }^{5}$ In line with Asiriyan et al. (2019), we find that tighter monetary policy results in lower stock prices except in the case of Chile. Both Granville and Mallick (2009) and Cocriş and Nucu (2013) define financial stability in terms of the change in the share price, the exchange rate as the units of local currency per unit of Euro and the loan-to-deposit ratio. Cocriş and Nucu (2013) find that in countries with inflation-targeting schemes, the interest rate instrument facilitates financial stability while, in countries with fixed exchange rates, monetary policy does not encourage financial stability except in the case of Bulgaria. Lastly, we include industrial production as a proxy for the real business cycle in line with Cocriş and Nucu (2013), Grilli and Roubini (1996), Kim (2001) and Kim and Roubini (2000).

Today, the Chilean Central Bank maintains one of the highest levels of Central Bank independence globally and maintains a successful inflation-targeting framework. Colombia is currently Latin America's second largest economy, has a stable currency, an abundance of natural resources, a somewhat stable political system and is seen as one of the greatest success stories globally over the past three decades. Chile is the largest producer of copper globally and Colombia's biggest export is oil; the currently decreased demand as well as plummeting prices in the midst of the COVID-19 pandemic poses a significant risk to both economies. These two countries have been overlooked in empirical research, much like other Latin American countries, for a multitude of reasons including the lack of data availability. The adoption of inflation-targeting regimes in the late 1990s has, however, sparked an interest in the monetary policy mechanism. SVAR models have been used to study both monetary policy (Catão and Pagan 2011; Parrado 2001) and fiscal policy (Restrepo and Rincon 2006) in Chile and Colombia. The number of papers implementing this methodology and focusing on the relationship between monetary policy and financial stability is, however, still somewhat limited. Japan, the world's third largest economy, is still toiling against lifelong employment, declining exports, strict immigration policies and stagflation all of which has been further amplified by the current global pandemic; this recently resulted in the country slipping into a recession. Earlier literature studying Japanese monetary policy using an SVAR model includes Nakahira (2009), Schenkelberg and Watzka (2013) and Yanoy and Yoshinoz (2009).

The Portuguese recovery in the aftermath of the Sovereign Debt Crisis is arguably the greatest success story in Southern Europe to date. Economically, Brexit has worsened investor confidence, resulted in weakened economic growth, higher debt levels and lower living standards. Politically, the UK has had three prime ministers in as many years which has resulted in stop-and-start Brexit negotiations and political disquietude. The uncommonly restricted economic activity in the midst of

\footnotetext{
4 Ouhibi and Hammami (2015) define financial stability in the same way.

5 The overhang effect refers to resources being moved away from investment and the wealth effect refers to bubbles reducing the cost of intermediation.
} 
the current COVID-19 pandemic, the unbridled pressure on financial resources and the excessive strain on governmental infrastructure will no doubt have a disastrously significant impact on the global economy and in particular, on both the Portuguese and the UK economies. SVAR models have been used to study monetary policy in earlier research focusing on the UK (Elbourne 2008; Caglayan et al. 2011) and both monetary policy and fiscal policy in Portugal (Sousa 2014; Afonso and Silva 2017; Afonso and Sousa 2011).

\section{Methodology and Data}

Hurwicz (1962) explains that a structural model is one in which the impact of 'interventions ${ }^{6}$ is predicted. This paper makes use of a SVAR model to identify the impact of interest rate policy on financial stability. I apply this methodology to the cases of Chile, Colombia, Japan, Portugal and the UK.

\section{Methodology}

Our starting point for the analysis is an SVAR model of order $\mathrm{p}(\operatorname{SVAR}(\mathrm{p}))$.

The SVAR model is as follows:

$$
B_{0} X_{t}=c+B_{1} X_{t-1}+B_{2} X_{t-2}+\cdots+B_{p} X_{t-p}+U_{t}
$$

$U_{t}$ is a multivariate white noise process with variance/covariance matrix $D$ and represents the structural innovations, $B_{i}$ and $D$ are $(K \times K)$ matrices, $c$ contains $K$ elements where $K$ is the number of variables with $i=0, \ldots, p$. There are $K(K-1) / 2$ restrictions on $B_{0}$ and in the case where $B_{0}$ is being lower triangular, there are $K(K+1) / 2$ unknowns in the matrix.

When $B_{0}$ is invertible, Eq. (1) is equivalent to Eq. (2) which represents a reducedform $\operatorname{VAR}(\mathrm{p})$ :

$$
X_{t}=\phi_{0}+\sum_{l=1}^{p} \Phi_{l} X_{t-l}+\varepsilon_{t}
$$

where $X_{t}$ is a $(K \times 1)$ vector of endogenous variables, $\phi_{0}$ is a $(K \times 1)$ vector of intercepts, $\Phi_{l}$ are $(K \times K)$ coefficient matrices and $\varepsilon_{t}=\left(\varepsilon_{1 t}, \varepsilon_{2 t}, \ldots, \varepsilon_{K t}\right)^{\prime}$ is an unobservable error term representing the reduced-form innovations with the following properties:

$$
\begin{gathered}
E\left[\varepsilon_{t}\right]=0 \\
E\left[\varepsilon_{t} \varepsilon_{s}^{\prime}\right]=0 \quad \forall t \neq s
\end{gathered}
$$

\footnotetext{
6 "Deliberate policy actions, or changes in the economy or in the nature of known types" (Sims 2002).
} 
and where Eq. (5) represents the relationship between the reduced-form shocks and structural shocks where $\varepsilon_{t}$ spans the space of the structural shocks $U_{t}$.

$$
\varepsilon_{t}=B_{0}^{-1} U_{t}
$$

An SVAR model allows for contemporaneous relationships between the variables and also allows us to study the effect of a shock to one equation while other shocks remain constant. This makes the SVAR model more appropriate than a reducedform VAR model in which error terms are correlated, and hence, error terms cannot be decomposed into mutually orthogonal shocks (Schenck 2016). This follows since,

$$
\left(\begin{array}{l}
u_{i p} \\
u_{i r} \\
u_{c g} \\
u_{s p} \\
u_{e r}
\end{array}\right)=\left(\begin{array}{lllll}
b_{11} & 0 & 0 & 0 & 0 \\
b_{21} & b_{22} & 0 & 0 & 0 \\
b_{31} & b_{32} & b_{33} & 0 & 0 \\
b_{41} & b_{42} & b_{43} & b_{44} & 0 \\
b_{51} & b_{52} & b_{53} & b_{54} & b_{55}
\end{array}\right) *\left(\begin{array}{l}
\varepsilon_{i p} \\
\varepsilon_{i r} \\
\varepsilon_{c g} \\
\varepsilon_{s p} \\
\varepsilon_{e r}
\end{array}\right) \begin{aligned}
& \text { Industrial production innovation } \\
& \text { Short term policy rates innovation } \\
& \text { Credit growth innovation } \\
& \text { Stock price innovation } \\
& \text { Exchange rate innovation }
\end{aligned}
$$

Following that $B_{0}$ is lower triangular, the Cholesky decomposition is used to construct the impulse responses to orthogonal/structural form shocks. These impulse response functions are generated in EViews and confidence intervals of 2 standard deviations based on 1000 replications are included in each generated impulse response function. The significance of shocks is interpreted at a 5\% level of significance as each impulse response function includes a $95 \%$ confidence interval. Shocks are statistical significant when the confidence interval does not contain zero. ${ }^{7}$ The order of the variables may be switched in multiple ways; however, existing literature justifies the ordering of the variables used in this paper. The ordering of the variables is in line with the ordering used by Cocriş and Nucu (2013) with the authors assuming that a recursive transmission scheme exists under the assumptions that firstly, industrial production is not immediately affected by monetary policy shocks and secondly, loan-to-deposit ratios (credit growth in this paper), stock indices and the exchange rate may be affected immediately by monetary policy shocks. The variables are ordered as above due to the assumption that industrial production affects all other variables contemporaneously. Geske and Roll (1983) find that changes in real activity, in our case growth in industrial production, lead to changes in money supply, in our case interest rate changes, and in turn, changes in the stock market. ${ }^{8}$

The ordering of our variables assumes that the exchange rate is affected contemporaneously by industrial production, interest rates, credit growth and the stock market which is in line with Hacker et al. (2012) who find evidence that the exchange rate is granger caused by the nominal interest rate differential. Robinson (1952)

\footnotetext{
7 I also conclude statistical significance in the cases where the confidence interval does not contain zero for the majority of periods included and also where a single band of the confidence interval is only marginally above or below zero.

${ }^{8}$ Kim (2003) also finds that stock price movements are driven, to some extent, by interest rate movements. Fama (1981) and Najand and Noronha (1998) show that industrial production is affected by both interest rates and inflation at a lag and, hence, not contemporaneously.
} 
argues that financial development follows economic growth. In our case, growth in industrial production has a contemporaneous effect on credit growth. Bartov and Bodnar (1994a, b) show that changes in the dollar affect current abnormal firm returns with a lag, this is in line with Angelos (2010) who finds that the volatility of the exchange rate in the US, the UK and Japan is largely determined by the volatility of home stock returns. ${ }^{9}$ The order of the variables is switched in two robustness checks to confirm the ordering of the primary matrix. The impulse response functions are not affected by the relevant changes in the ordering of the variables in any cases.

Three unit root analyses are conducted, namely the Augmented Dickey-Fuller (ADF) test, the Phillips-Perron (PP) unit root test and the Hylleberg, Engle, Granger and Yoo (HEGY). Both the PP test and the ADF test show that the year-on-year growth rates of all but two cases have an order of integration of $I(0)$, and hence, the growth rates are stationary. ${ }^{10}$ The third unit root test, the HEGY test, is included to account for the seasonally unadjusted data and the annual differencing used. When looking at the test statistics for frequency 0 , we fail to reject the null hypothesis of the presence of a unit root for the case of the stock market in Colombia, credit in Portugal and the exchange rate in Portugal. When considering the semi-annual frequency, annual frequency as well as the joint significance of the full set of unit roots (seasonal and non-seasonal frequencies), the null hypothesis is rejected in all cases, and therefore, no unit roots are present. In the case of the Colombian stock market and the Portuguese exchange rate, the presence of the unit root may be a small sample effect. The joint significance of the full set of unit roots is, however, rejected. The presence of unit roots should therefore, not be an issue in our sample.

\section{Data}

The GFC emphasized the need to focus on both financial stability and price stability as the primary objective of Central Banks prior to the GFC had been the maintenance of price stability. Three proxies for financial stability together with IPI to account for economic growth are included in the analysis with each proxy representing a sector of the economy which could potentially conceal financial stability risks (Cocriş and Nucu 2013). Monetary policy is represented by the short-term interest rate and the shadow rate in this paper, short-term interest rates are available from the IFS (for Chile) and the FRED (Colombia). In the case of the advanced economies, the shadow rate [Krippner $(2013,2015)$ shadow/lower bound framework] is used as a measure of monetary policy intervention. The shadow rate is used in the case of the advanced economies due to the inability of policy rates to fully capture the

\footnotetext{
9 Yang and Doong (2004) note that empirical evidence shows that changes in stock prices affect exchange rate movements; however, the impact of changes in the exchange rate on stock market prices is less significant. It is thought that stock markets have a more noticeable effect on exchange rates due to the deregulation of financial markets which has decreased the difficulty of and stimulated capital flows across borders.

${ }^{10}$ Results available on request.
}

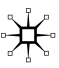


extent of monetary policy intervention in the presence of quantitative easing and other unconventional monetary policy tools. The use of the shadow rate allows one to see the effect of monetary policy tools on factors such as the unemployment rate and industrial production without the limitation of the zero-lower bound on policy rates.

The relevant variables are as follows:

- Credit growth as a proxy for the banking system (BIS total credit statistics);

- Stock index as a proxy for the capital market (Federal Reserve Economic Data);

- The exchange rate measured as local currency units per unit of US dollar as a proxy for the foreign exchange market (Federal Reserve Economic Data), exchange rates quoted as US dollar units per unit of local currency are converted;

- Industrial production as a proxy for economic growth (Federal Reserve Economic Data).

Ivanov and Kilian (2001) suggest that the Akaike Information Criterion (AIC) is appropriate when considering monthly data, the Hannan-Quinn Information Criterion (HQIC) is appropriate when considering quarterly data with a sample size larger than 120 observations and the Schwarz Bayesian Information Criterion (SBIC) is appropriate when considering quarterly data with any sample size. The SBIC suggests that 2 lags be used for the case of Chile while 1 lag is suggested for the case of Portugal. All three information criteria suggest that 2 lags be used for the case of Colombia while 1 lag is suggested for the case of Japan. Lastly, the HQIC and the SBIC suggest 1 lag for the case of the UK.

The dataset created contains data for Chile between 2004Q3 and 2018Q4, Colombia between 2003Q1 and 2016Q1, Japan between 1996Q2 and 2018Q2, Portugal between 2000Q2 and 2018Q2 and the UK between 1996Q2 and 2018Q2. Breaks exist in the dataset, the number of observations quoted below is based on a balanced SVAR estimation with the suggested number of lags. The SVAR and the resulting impulse response functions therefore have the following number of observations. Chile has 58 observations, Colombia has 53 observations, Japan has 82 observations, Portugal has 75 observations and the UK has 91 observations. To assess the extent to which the differing sample periods may affect the results, a robustness check, the results of which are not statistically significantly different, limiting the sample period to the period between 2004:Q3 and 2016:Q1 is conducted. Figure 1 plots the quarterly Central Bank policy rate for the five countries as well as the shadow rates for Japan, Portugal and the UK over the period between 1960 and 2019.

\section{Empirical Results}

\section{Main Results}

Table 1 summarizes the responses of the individual variables to shocks in the Central Bank policy rate (Chile and Colombia) and the shadow rate (Japan, Portugal 


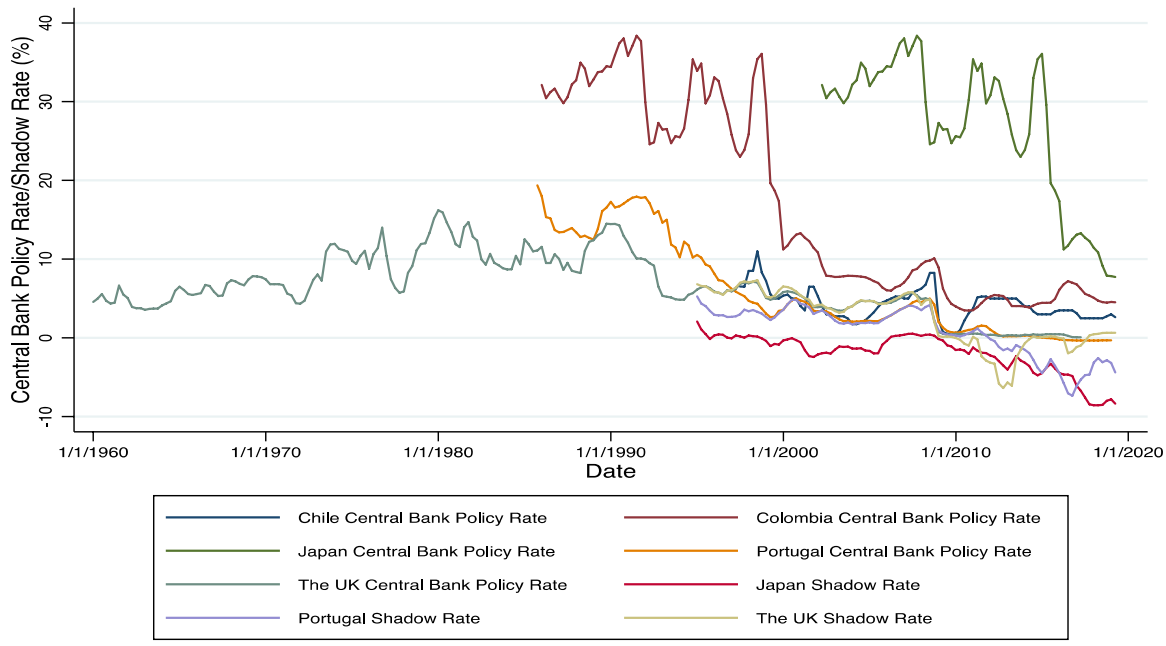

Fig. 1 Quarterly Central Bank Policy Rates and shadow rates for Chile, Colombia, Japan, Portugal and the UK. Source IFS, FRED, Krippner $(2013,2015)$

Table 1 Summary of responses of variables to a Central Bank Policy Shock (quarterly data)

\begin{tabular}{llllll}
\hline & Chile & Colombia & Japan & Portugal & The UK \\
\hline Variables & & & & & \\
Short run response & & & & & \\
$\quad$ Industrial production index & $+^{*}$ & - & - & - & + \\
Credit & - & $+^{*}$ & + & + & - \\
Stock market index & $+^{*}$ & $-*$ & - & - & - \\
Exchange rate & - & $+^{*}$ & - & - & + \\
Long run response & & & & & + \\
Industrial production index & $+^{*}$ & $-^{*}$ & - & - & - \\
Credit & $-*$ & $+^{*}$ & + & $+^{*}$ & - \\
Stock market index & $+^{*}$ & $-^{*}$ & - & - & + \\
Exchange rate & - & $+^{*}$ & - & $-*$ & - \\
\hline
\end{tabular}

- , Negative response; + , positive response

*Statistically significant response at $5 \%$ level

and the UK). In three of the five cases (Colombia, Japan and Portugal), industrial production declines following a monetary policy shock while, for Chile and the UK, industrial production increases. This result is statistically significant for the case of Chile. Similarly, the former three cases experience an increase in credit growth following a monetary policy shock while the latter experiences a decline. These results are statistically significant in the case of Colombia in the short run and the cases of Chile, Colombia and Portugal in the long run. The level of the stock market index declines in four of the five cases with the level decreasing in the case of Chile. These 
Table 2 Summary of responses of variables to a Central Bank Policy Shock (monthly data)

\begin{tabular}{llllll}
\hline & Chile & Colombia & Japan & Portugal & The UK \\
\hline Variables & & & & & \\
Short run response & & & & & \\
$\quad$ Industrial production index & - & $-*$ & + & - & + \\
Credit & $-*$ & + & $-*$ & - & + \\
Stock market index & $+^{*}$ & $-*$ & + & - & - \\
Exchange rate & - & $+^{*}$ & - & - & - \\
Long run response & & & & & + \\
Industrial production index & - & - & + & - & - \\
Credit & $-*$ & $+^{*}$ & $-*$ & - & - \\
Stock market index & $+*$ & $-*$ & $+^{*}$ & - & - \\
Exchange rate & - & $+^{*}$ & - & - & - \\
\hline
\end{tabular}

- , Negative response; + , positive response

*Statistically significant response at $5 \%$ level

results are statistically significant for Chile and Colombia in both the short run and the long run. Finally, the exchange rate declines in three of the cases (Chile, Japan and Portugal) and increases for the cases of Colombia and the UK. This corresponds to an appreciation of the local currencies for the first three cases following a monetary policy shock which is in line with conventional wisdom while, for the cases of Colombia and the UK, the currency depreciates. These results are statistically significant for the case of Colombia in the short run and Colombia and Portugal in the long run.

\section{Robustness Checks}

A number of robustness checks are conducted in an effort to validate the results. A robustness check using monthly data (Table 2) is included as the accuracy of an SVAR model increases as the number of observations increases. The results show that there is a sign change for the case of industrial production for Chile with the sign being positive and statistically significant when considering quarterly data and the sign becoming negative without statistical significance when considering monthly data. Both industrial production and the stock market have a sign change for the case of Japan, credit has a sign change for the case of Portugal and both the exchange rate and credit have a sign change for the UK. Neither the results for these cases in the original sample nor the results for these cases in the monthly dataset are statistically significant. Lastly, there is a sign change for credit in Japan with the sign changing from positive to statistically significant and negative.

A second robustness check (Table 3) using monthly log data shows that the exchange rate depreciated after an interest rate shock in the case of Chile and Colombia while the exchange rate appreciates in the case of Japan, Portugal and the UK in line with conventional wisdom. 
Table 3 Summary of responses of variables to a Central Bank Policy Shock (monthly log data)

\begin{tabular}{|c|c|c|c|c|c|}
\hline & Chile & Colombia & Japan & Portugal & The UK \\
\hline \multicolumn{6}{|l|}{ Variables } \\
\hline \multicolumn{6}{|l|}{ Short run response } \\
\hline Industrial production index & + & - & - & - & + \\
\hline Credit & + & - & + & + & - \\
\hline Stock market index & - & $-*$ & + & - & - \\
\hline Exchange rate & + & $+^{*}$ & - & - & - \\
\hline \multicolumn{6}{|l|}{ Long run response } \\
\hline Industrial production index & + & + & - & + & $+^{*}$ \\
\hline Credit & $+^{*}$ & $-*$ & $+^{*}$ & $+^{*}$ & + \\
\hline Stock market index & $-*$ & $-*$ & + & - & - \\
\hline Exchange rate & + & $+*$ & - & - & - \\
\hline
\end{tabular}

-, Negative response; + , positive response

*Statistically significant response at $5 \%$ level

Table 4 Summary of responses of variables to a Central Bank Policy Shock (quarterly with adjusted starting date)

\begin{tabular}{|c|c|c|c|c|c|}
\hline & Chile & Colombia & Japan & Portugal & The UK \\
\hline \multicolumn{6}{|l|}{ Variables } \\
\hline \multicolumn{6}{|l|}{ Short run response } \\
\hline Industrial production index & + & - & - & - & - \\
\hline Credit & $-*$ & + & + & + & - \\
\hline Stock market index & $+^{*}$ & $-*$ & + & - & - \\
\hline Exchange rate & $-*$ & $+^{*}$ & + & - & + \\
\hline \multicolumn{6}{|l|}{ Long run response } \\
\hline Industrial production index & $+^{*}$ & $-*$ & - & $-*$ & - \\
\hline Credit & $-*$ & $+^{*}$ & + & + & - \\
\hline Stock market index & $+^{*}$ & $-*$ & + & - & - \\
\hline Exchange rate & $-*$ & $+^{*}$ & + & -* & - \\
\hline
\end{tabular}

- , Negative response; + , positive response

*Statistically significant response at $5 \%$ level

A third robustness check (Table 4) using quarterly data, however, adjusting the start date and end date of the data to ensure that the period studied remains constant for all cases is included. This robustness check studies the period between 2004:Q3 and 2016:Q1. The results show that there is a sign change for the UK for industrial production when limiting the time period and there is no sign change for credit growth in any of the cases. The results also show that there is a sign change for Japan for the stock market as well as a sign change for Japan and the UK for the exchange rate. Similarly to the first robustness check, neither the results for these cases in the original sample nor the results for these cases in the limited sample are statistically significant. One may therefore conclude that the difference in sample periods across countries does not affect the results in a statistically significant way. 
Table 5 Summary of responses of variables to a Central Bank Policy Shock (quarterly data with adjusted order)

\begin{tabular}{llllll}
\hline & Chile & Colombia & Japan & Portugal & The UK \\
\hline Variables & & & & & \\
Short run response & & & & & \\
$\quad$ Industrial production index & + & - & - & - & + \\
Credit & $-*$ & $+^{*}$ & + & + & - \\
Stock market index & $+^{*}$ & $-*$ & - & - & - \\
Exchange rate & - & $+^{*}$ & - & - & + \\
Long run response & & & & & + \\
Industrial production index & + & $-^{*}$ & - & - & - \\
Credit & $-*$ & $+^{*}$ & + & + & - \\
Stock market index & $+^{*}$ & $--^{*}$ & - & - & + \\
Exchange rate & $-*$ & $+^{*}$ & - & $-*$ & + \\
\hline
\end{tabular}

- , Negative response; + , positive response

*Statistically significant response at $5 \%$ level

Table 6 Summary of responses of variables to a Central Bank Policy Shock (quarterly data with adjusted order)

\begin{tabular}{llllll}
\hline & Chile & Colombia & Japan & Portugal & The UK \\
\hline Variables & & & & & \\
Short run response & & & & & \\
$\quad$ Industrial production index & - & $-*$ & + & - & + \\
Credit & $-*$ & + & $-*$ & - & + \\
Stock market index & $+^{*}$ & $-*$ & + & - & - \\
Exchange rate & - & $+^{*}$ & - & - & - \\
Long run response & & & & & + \\
Industrial production index & - & - & + & - & - \\
Credit & $-*$ & $+^{*}$ & $-*$ & - & - \\
Stock market index & $+*$ & $-*$ & $+^{*}$ & - & - \\
Exchange rate & - & $+^{*}$ & - & - & - \\
\hline
\end{tabular}

Further, two robustness checks (Tables 5,6) using a different ordering of variables and quarterly data are included to check whether a change in the ordering of the variables leads to a change in the results. Table 5 presents the results of the case where the position of the short-term policy rates innovation and the industrial production innovation are switched, while Table 6 presents the results of the case where the position of the stock price innovation and the exchange rate innovation are switched. There are no sign changes resulting from the change in variable ordering.

Finally, to add to the robustness of the results, a sixth robustness check (Table 7) using quarterly data and a BVAR model is employed. The BVAR model is used as a robustness check to address the concern arising from the small sample size as BVAR models have a shrinkage estimator, which adjusts coefficients to match the 
Table 7 Summary of responses of variables to a Central Bank Policy Shock (quarterly BVAR)

\begin{tabular}{llllll}
\hline & Chile & Colombia & Japan & Portugal & The UK \\
\hline Variables & & & & & \\
Short run response & & & & & \\
$\quad$ Industrial production index & + & - & + & - & - \\
Credit & - & + & + & + & - \\
Stock market index & + & - & - & - & - \\
Exchange rate & - & + & - & - & - \\
Long run response & & & & & - \\
$\quad$ Industrial production index & + & - & + & - & - \\
Credit & - & + & + & + & - \\
Stock market index & + & - & - & - & - \\
Exchange rate & - & + & - & - & - \\
\hline
\end{tabular}

- , Negative response; + , positive response

data observed and permits the optimization of the dataset. A distinct advantage of the BVAR model is the lack of a requirement to limit the number of coefficients to be estimated as this model makes use of a prior; in this case, the Minessota prior introduced in Litterman (1979) is used. The use of the Minessota prior and hence a random walk prior is appropriate in this analysis (Litterman 1979). This is due to the random behavior of macroeconomic time series as well as the flexibility of the restrictions imposed. The results are similar to those of the main results of this paper, with the sign of the change staying the same for the majority of cases with the exception of industrial production for Japan and the UK and the exchange rate for the UK. In the remaining cases, the magnitude of the effect of the shock becomes slightly smaller.

\section{Conclusion}

The financial turmoil caused by the GFC highlighted the importance of financial stability and resulted in the relationship between financial stability and monetary policy becoming an important element when policy mandates were updated in the period after the crisis. In this paper, the impact of monetary policy shocks on financial stability for the cases of Chile, Colombia, Japan, Portugal and the UK is analyzed. The five countries chosen have autonomous, inflation-targeting Central Banks with floating exchange rate regimes in place, which allows us to analyze the impact of monetary policy shocks on five countries with similar policy mandates. The set of countries presents an interesting case with Colombia and Chile being categorized as emerging economies with a history of limited availability of data, the UK and Japan facing political uncertainty and economic uncertainty, respectively, and finally, Portugal which experienced the most profound economic growth in the group of countries that received an injection of European funding. 
An SVAR model is employed and impulse response functions are used in an effort to test the impact of monetary policy on financial stability. Credit growth, the stock market index growth and the exchange rate growth are included as proxies for financial stability while industrial production growth is included as a proxy for the business cycle. As in Cocriş and Nucu (2013), the impact of short-term interest rates and shadow rates on three proxies for financial stability, namely credit growth, stock prices and the exchange rate, is studied. Industrial production is included as a proxy for the real sector and hence for economic growth. In line with Cocriş and Nucu (2013), policy rates are used to represent monetary policy choices in emerging economies. Shadow rates are used to represent monetary policy intervention in advanced economies.

Our main results show that monetary policy may be used to correct asset mispricing due to the inverse relationship between the policy rate and the stock market index for the majority of cases namely, Colombia, Japan, Portugal and the UK. Conventional wisdom suggests that a positive monetary policy shock would result in a currency appreciation in countries with a floating exchange rate regime as foreign investment is attracted. The results show that the exchange rate appreciates in both the short run and the long run following a monetary policy shock for three of the five cases, namely the cases of Chile, Japan and Portugal while the currency depreciates for the cases of Colombia and the UK. The currency depreciation in the case of Colombia could be attributed to Colombia's reliance on commodity exports. The currency depreciation in the case of the UK is in line with earlier literature including Caglayan et al. (2011) and is attributed to uncertainty in the local market.

The results also show that monetary policy may be used to control fluctuations in the real business cycle as can be seen by the inverse relationship between the industrial production index and monetary policy shocks for the cases of Colombia, Japan and Portugal. Credit growth also has an inverse relationship with monetary policy shocks for the cases of Chile and the UK. Consequently, monetary policy may be used to tame credit cycles in some cases. However, in the majority of cases, namely Colombia, Japan and Portugal, there is a positive relationship between credit and monetary policy shocks. Monetary policy intervention, as represented by policy rates in the cases of emerging market economies and shadow rates in the cases of advanced economies, may indeed be successful at contributing to or achieving financial stability. However, our results show that monetary policy may not have the ability to maintain or re-establish financial stability in all cases. Alternative policy choices such as macroprudential policy tool frameworks which are aimed at targeting the financial system as a whole may be implemented to buttress the economy.

Acknowledgements I am grateful to Nuno Sobreira and Harald Badinger for their useful comments at the INFER Workshop on New Challenges for Fiscal Policy on an earlier version of this paper. I am also grateful to both anonymous reviewers at the Journal of Comparative Economic Studies and to André Teixeira for the useful comments. Lastly, I am also grateful to António Afonso for his useful comments. 
Response of Industrial

Production to Central

Bank Policy Rate

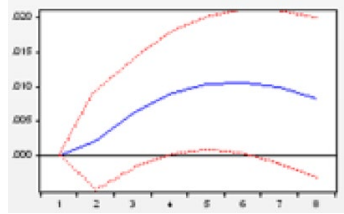

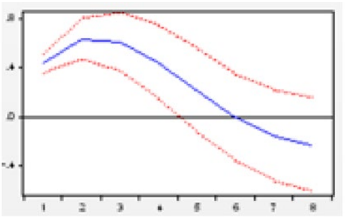

Response of Credit to

Central Bank Policy Rate

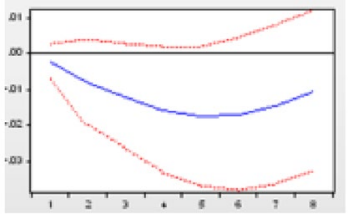

Response of Stock Market

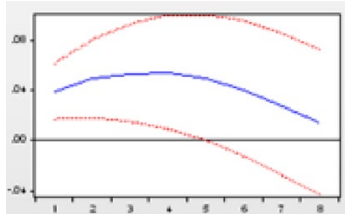

Response of Exchange

Rate to Central Bank

Policy Rate

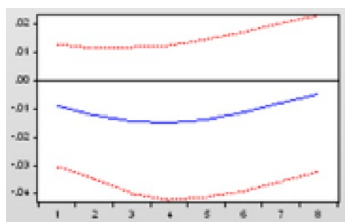

to Central Bank Policy

Rate

Fig. 2 Short run structural impulse response function: Chile. Responses of industrial production, the Central Bank policy rate, credit, stock market and the exchange rate in Chile to a Central Bank policy rate shock. A confidence interval of 2 standard deviations based on 1000 replications is included

Response of Industrial

Production to Central

Bank Policy Rate

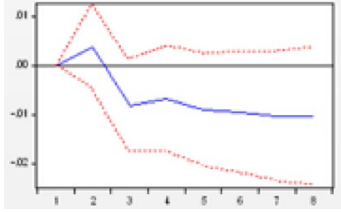

Response of Central Bank

Policy Rate to Central
Bank Policy Rate

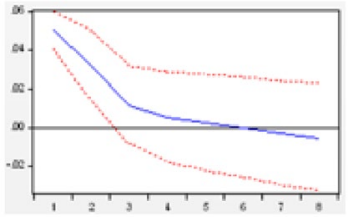

Response of Credit to

Central Bank Policy Rate

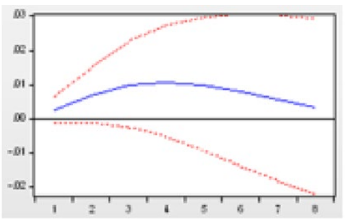

Response of Stock Market
Rate

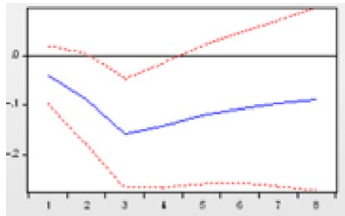

Response of Exchange

Rate to Central Bank

Policy Rate

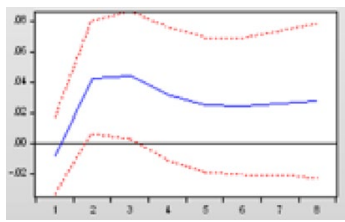

to Central Bank Policy

Fig. 3 Short run structural impulse response function: Colombia. Responses of industrial production, the Central Bank policy rate, credit, stock market and the exchange rate in Colombia to a Central Bank policy rate shock. A confidence interval of 2 standard deviations based on 1000 replications is included 
Response of Industrial

Production to Shadow

Rate

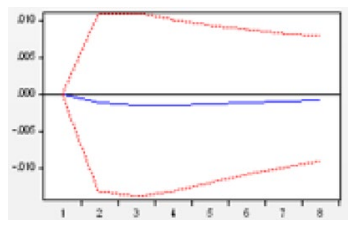

Response of Shadow Rate

to Shadow Rate

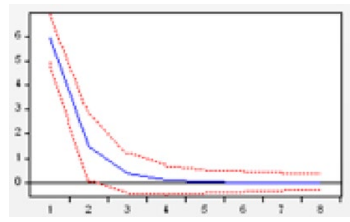

Response of Exchange

Response of Credit to

Rate to Shadow Rate

Shadow Rate
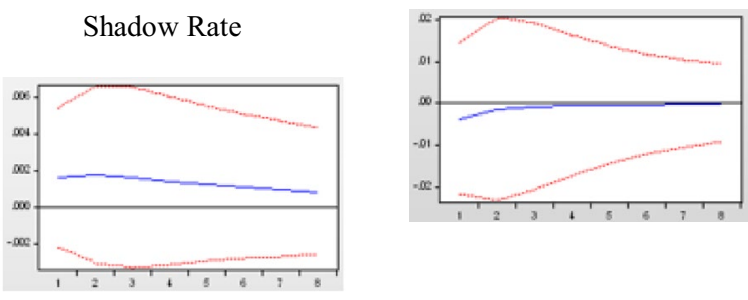

Response of Stock Market

to Shadow Rate

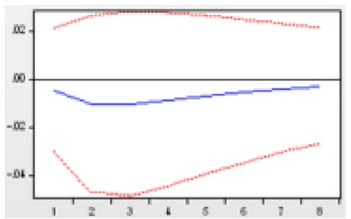

Fig. 4 Short run structural impulse response function: Japan. Responses of industrial production, the shadow rate, credit, stock market and the exchange rate in Japan to a shadow rate shock. A confidence interval of 2 standard deviations based on 1000 replications is included

\section{Appendix A}

\section{Structural Impulse Response Functions: Short Run Impact}

\section{Chile}

See Fig. 2.

\section{Colombia}

See Fig. 3.

Japan

See Fig. 4. 
Response of Industrial

Production to Shadow

Rate

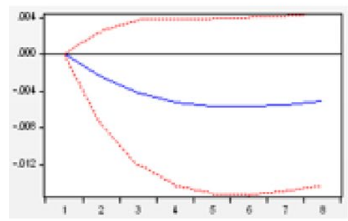

Response of Shadow Rate

to Shadow Rate

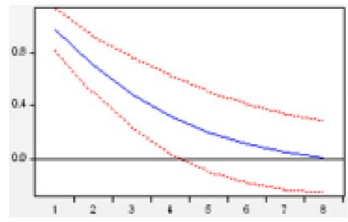

Response of Exchange

Response of Credit to

Shadow Rate

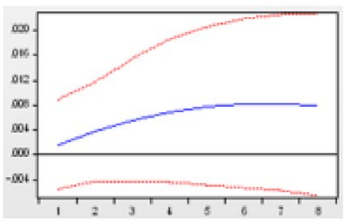

Response of Stock Market

to Shadow Rate

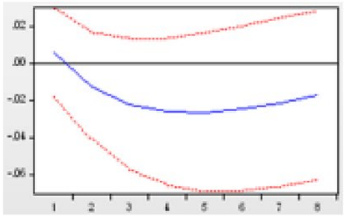

Rate to Shadow Rate

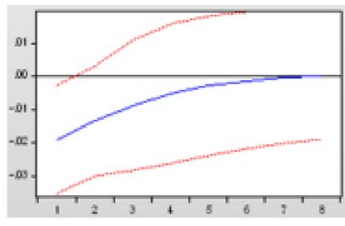

Fig. 5 Short run structural impulse response function: Portugal. Responses of industrial production, the shadow rate, credit, stock market and the exchange rate in Portugal to a shadow rate shock. A confidence interval of 2 standard deviations based on 1000 replications is included

\section{Portugal}

See Fig. 5.

\section{The UK}

See Fig. 6.

\section{Cumulative structural impulse response functions: long run impact}

\section{Chile}

See Fig. 7.

\section{Colombia}

See Fig. 8. 
Response of Industrial

Production to Shadow

Rate

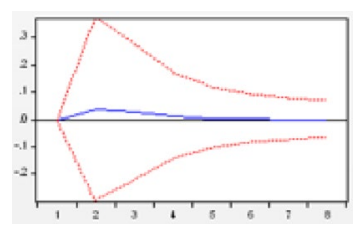

Response of Shadow Rate

to Shadow Rate

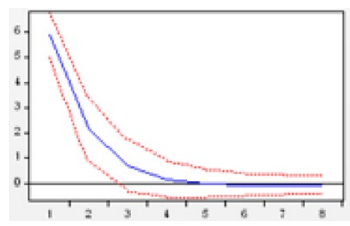

Response of Exchange

Response of Credit to

Shadow Rate

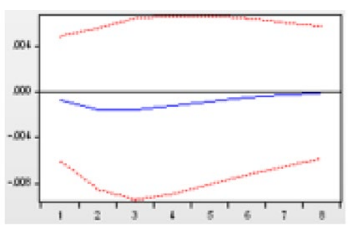

Response of Stock Market

to Shadow Rate

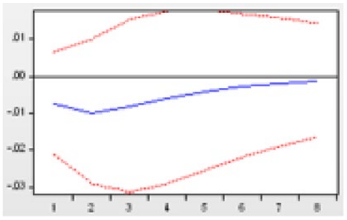

Fig. 6 Short run structural impulse response function: The UK. Responses of industrial production, the shadow rate, credit, stock market and the exchange rate in the UK to a shadow rate shock. A confidence interval of 2 standard deviations based on 1000 replications is included

\section{Japan}

See Fig. 9.

\section{Portugal}

See Fig. 10.

\section{The UK}

See Fig. 11. 
Response of Industrial

Production to Central

Bank Policy Rate

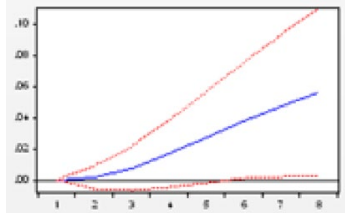

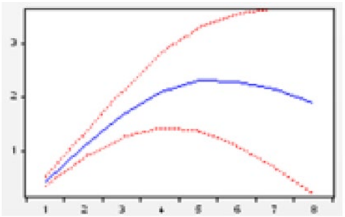

Response of Credit to

Central Bank Policy Rate

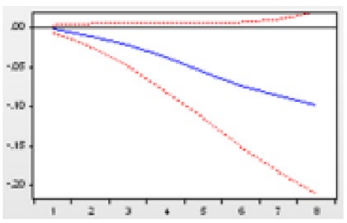

Response of Stock Market

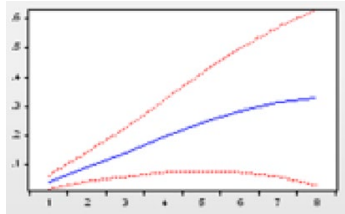

Response of Exchange

Rate to Central Bank

Policy Rate

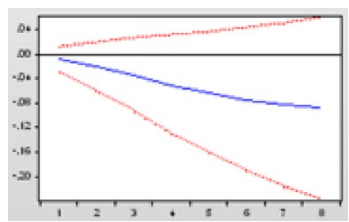

to Central Bank Policy

Rate

Fig. 7 Long run structural impulse response function: Chile. Responses of industrial production, the Central Bank policy rate, credit, stock market and the exchange rate in Chile to a Central Bank policy rate shock. A confidence interval of 2 standard deviations based on 1000 replications is included

\section{Response of Industrial \\ Production to Central \\ Bank Policy Rate}

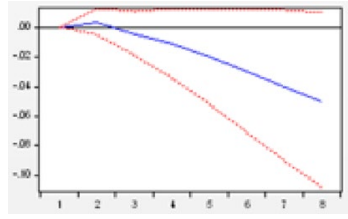

Response of Central Bank

Policy Rate to Central

Bank Policy Rate

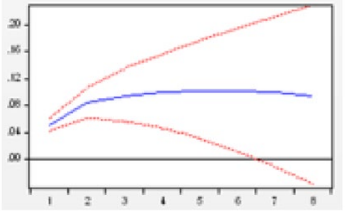

Response of Credit to

Central Bank Policy Rate

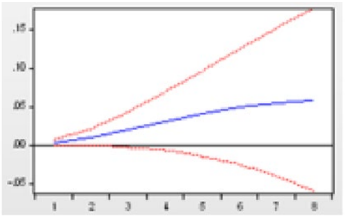

Response of Stock Market

to Central Bank Policy

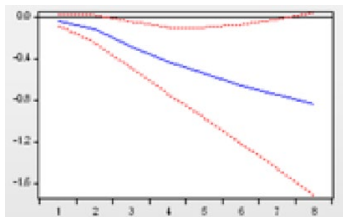

Response of Exchange

Rate to Central Bank

Policy Rate

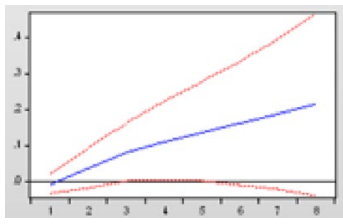

Rate

Fig. 8 Long run structural impulse response function: Colombia. Responses of industrial production, the Central Bank policy rate, credit, stock market and the exchange rate in Colombia to a Central Bank policy rate shock. A confidence interval of 2 standard deviations based on 1000 replications is included 望。 
Response of Industrial

Production to Shadow

Rate

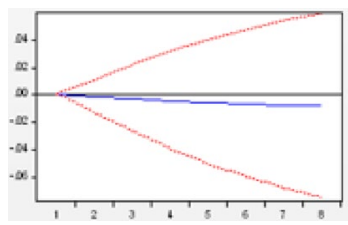

Response of Shadow Rate

to Shadow Rate

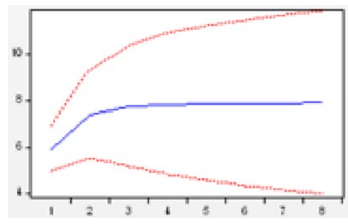

Response of Exchange

Response of Credit to

Rate to Shadow Rate

Shadow Rate
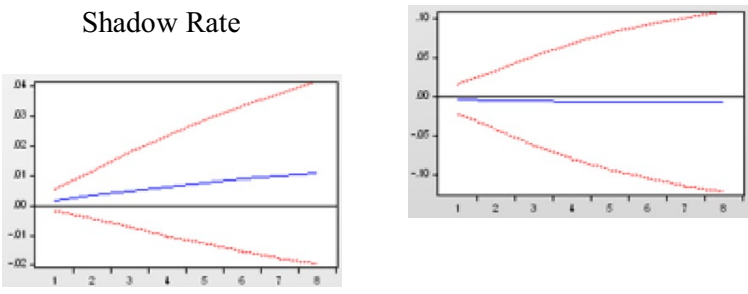

Fig. 9 Long run structural impulse response function: Japan. Responses of industrial production, the shadow rate, credit, stock market and the exchange rate in Japan to a shadow rate shock. A confidence interval of 2 standard deviations based on 1000 replications is included

Response of Industrial

Production to Shadow

Rate

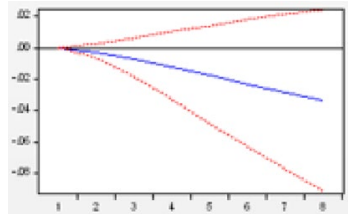

Response of Shadow Rate

to Shadow Rate

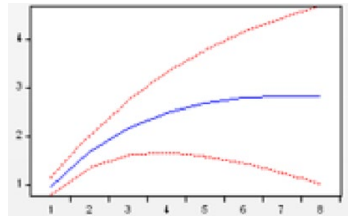

Response of Exchange

Response of Credit to

Rate to Shadow Rate

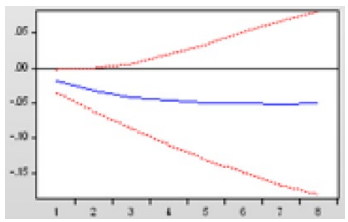

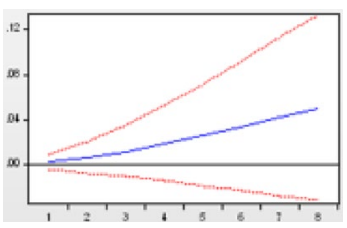

Response of Stock Market

to Shadow Rate

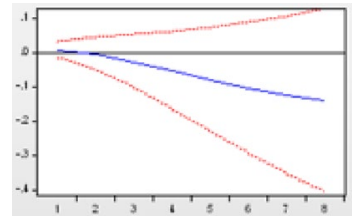

Fig. 10 Long run structural impulse response function: Portugal. Responses of industrial production, the shadow rate, credit, stock market and the exchange rate in Portugal to a shadow rate shock. A confidence interval of 2 standard deviations based on 1000 replications is included 


\section{Response of Industrial}

Production to Shadow

Rate

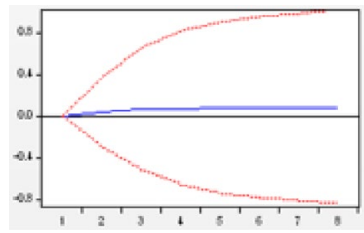

Response of Shadow Rate

to Shadow Rate

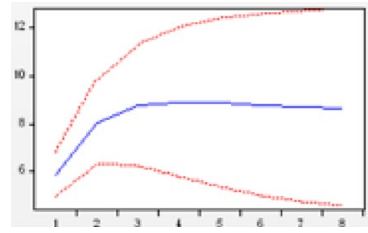

\section{Response of Credit to}

Shadow Rate

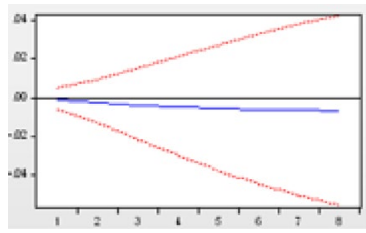

Response of Stock Market

to Shadow Rate

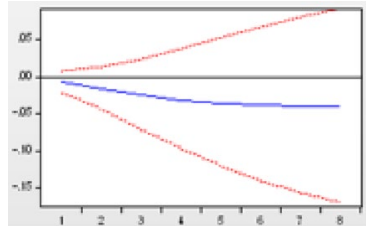

Response of Exchange

Rate to Shadow Rate

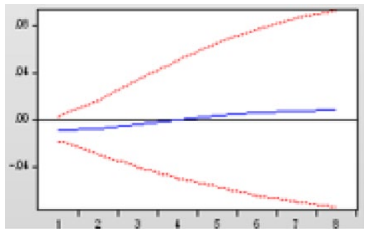




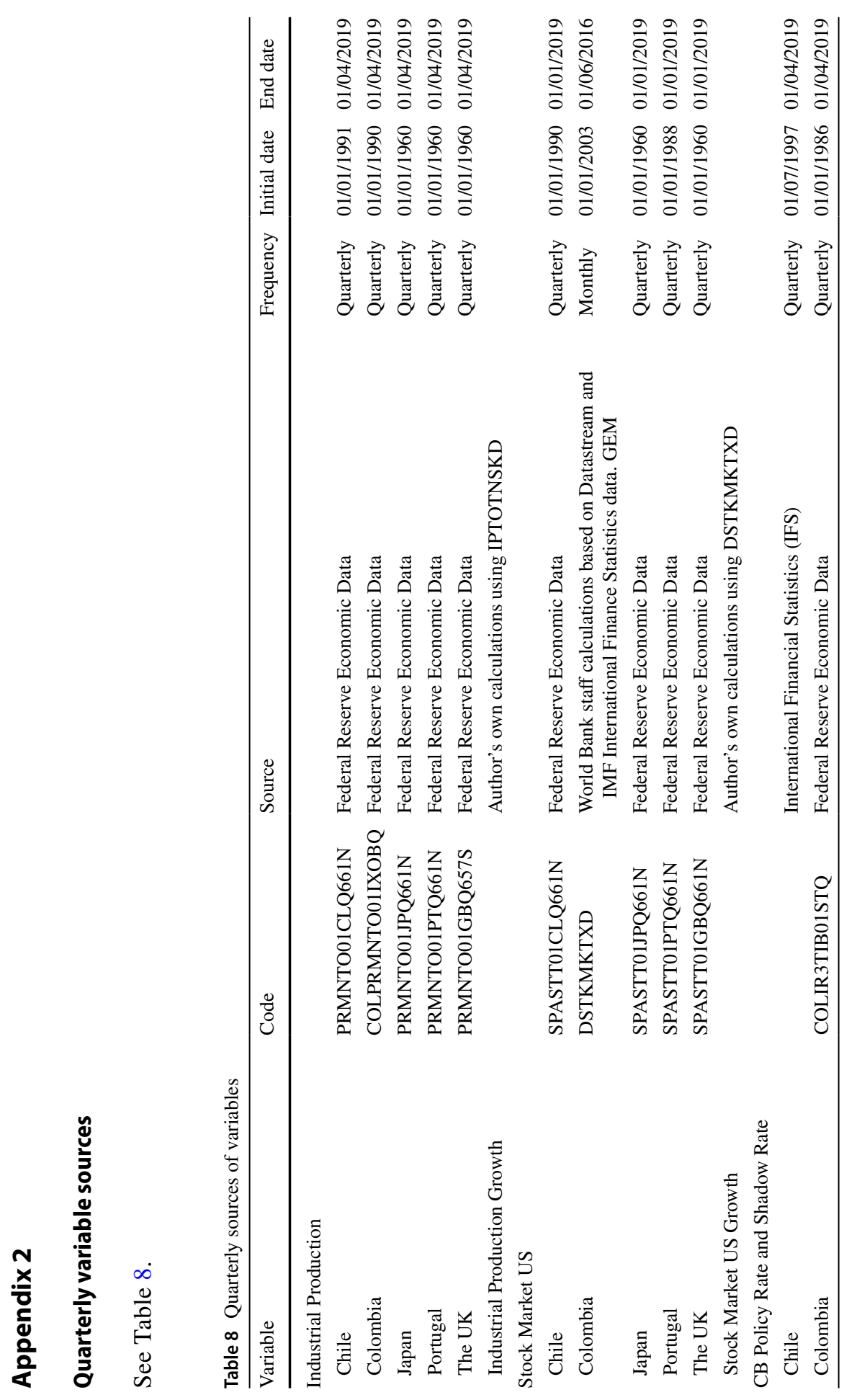




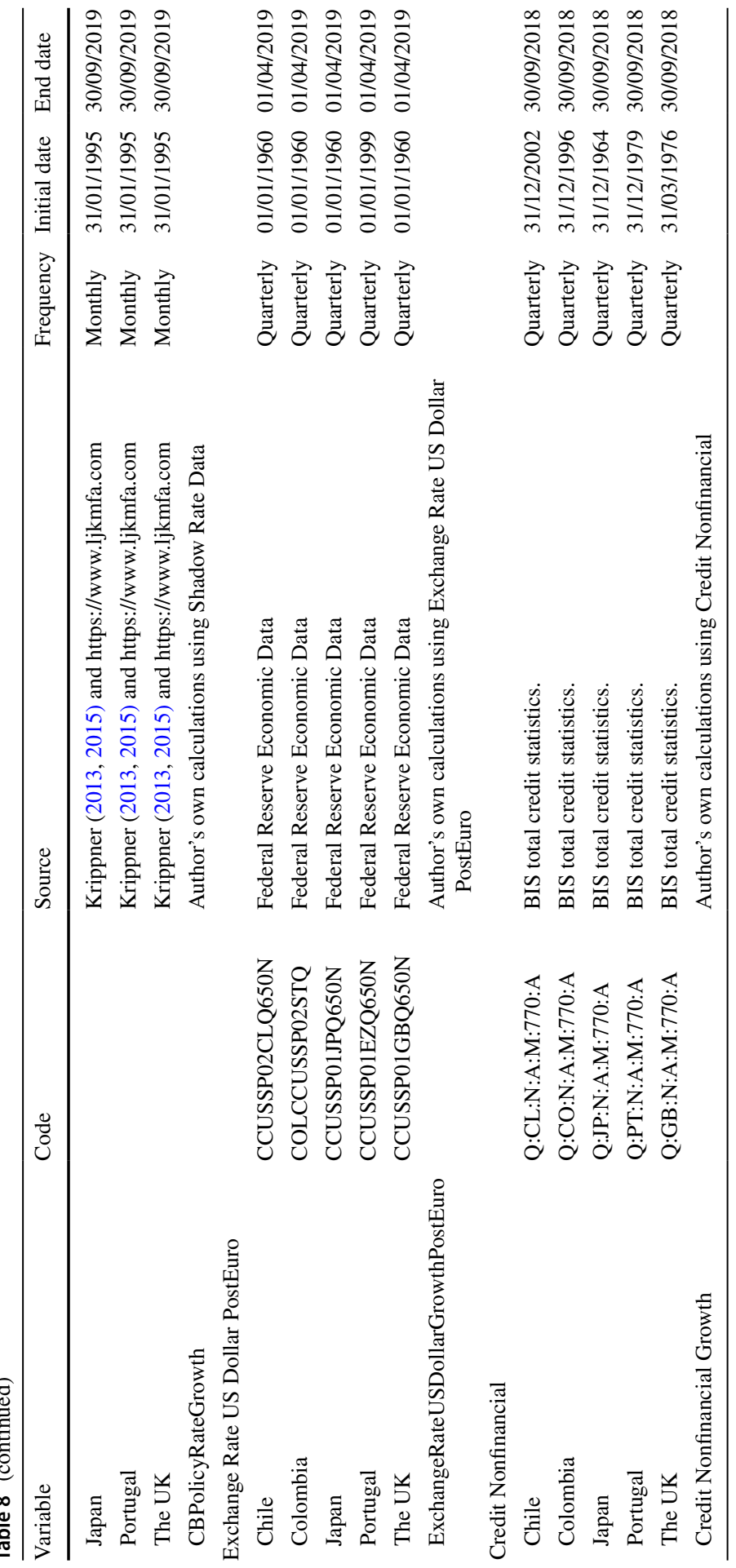

我造 


\section{Quarterly variable definitions}

See Table 9.

Table 9 Quarterly definitions of variables

\begin{tabular}{|c|c|}
\hline Variable & Description \\
\hline \multicolumn{2}{|l|}{ Industrial Production } \\
\hline Chile & $\begin{array}{l}\text { Total manufacturing production for Chile, Index } \\
2015=100 \text {, quarterly, not seasonally adjusted }\end{array}$ \\
\hline Colombia & $\begin{array}{l}\text { Production: manufacturing: total manufacturing: total } \\
\text { manufacturing for Colombia, Index } 2015=100 \text {, quar- } \\
\text { terly, not seasonally adjusted }\end{array}$ \\
\hline Japan & $\begin{array}{l}\text { Total manufacturing production for Japan, Index } \\
2015=100 \text {, quarterly, not seasonally adjusted }\end{array}$ \\
\hline Portugal & $\begin{array}{l}\text { Total manufacturing production for Portugal, Index } \\
2015=100 \text {, quarterly, not seasonally adjusted }\end{array}$ \\
\hline The UK & $\begin{array}{l}\text { Total manufacturing production for the UK, growth rate } \\
\text { previous period, quarterly, seasonally adjusted }\end{array}$ \\
\hline Industrial Production Growth & Growth rate in industrial production \\
\hline \multicolumn{2}{|l|}{ Stock Market US } \\
\hline Chile & $\begin{array}{l}\text { Total share prices for all shares for Chile, Index } \\
2015=100 \text {, quarterly, not seasonally adjusted }\end{array}$ \\
\hline Colombia & $\begin{array}{l}\text { Local equity market index valued in US\$ terms. Monthly } \\
\text { data averaged to quarterly }\end{array}$ \\
\hline Japan & $\begin{array}{l}\text { Total share prices for all shares for Japan, Index } \\
2015=100 \text {, quarterly, not seasonally adjusted }\end{array}$ \\
\hline Portugal & $\begin{array}{l}\text { Total share prices for all shares for Portugal, Index } \\
2015=100 \text {, quarterly, not seasonally adjusted }\end{array}$ \\
\hline The UK & $\begin{array}{l}\text { Total share prices for all shares for the UK, Index } \\
2015=100 \text {, quarterly, not seasonally adjusted }\end{array}$ \\
\hline Stock Market US Growth & Growth rate in equity market index valued in US\$ \\
\hline \multicolumn{2}{|l|}{ CB Policy Rate } \\
\hline Chile & $\begin{array}{l}\text { Financial, interest rates, monetary policy-related interest } \\
\text { rate, percent per annum }\end{array}$ \\
\hline Colombia & $\begin{array}{l}\text { Interest rates: } 3 \text {-month or } 90 \text {-day rates and yields: inter- } \\
\text { bank rates: total for Colombia, percent, quarterly, not } \\
\text { seasonally adjusted }\end{array}$ \\
\hline Japan & Monthly average shadow short rate (SSR) estimates \\
\hline Portugal & Monthly average shadow short rate (SSR) estimates \\
\hline The UK & Monthly average shadow short rate (SSR) estimates \\
\hline CB Policy Rate Growth & Growth rate in Central Bank policy rates/shadow rates \\
\hline \multicolumn{2}{|c|}{ Exchange Rate US Dollar PostEuro } \\
\hline Chile & $\begin{array}{l}\text { National currency to US dollar spot exchange rate for } \\
\text { Chile, US Dollar per National Currency Units, quar- } \\
\text { terly, not seasonally adjusted }\end{array}$ \\
\hline
\end{tabular}


Table 9 (continued)

\begin{tabular}{|c|c|}
\hline Variable & Description \\
\hline Colombia & $\begin{array}{l}\text { Currency conversions: US\$ exchange rate: spot, end of } \\
\text { period: national currency: USD for Colombia, National } \\
\text { Currency Units per US Dollar, quarterly, not seasonally } \\
\text { adjusted }\end{array}$ \\
\hline Japan & $\begin{array}{l}\text { US Dollar to national currency spot exchange rate for } \\
\text { Japan, US Dollar per National Currency Units, quar- } \\
\text { terly, not seasonally adjusted }\end{array}$ \\
\hline Portugal & $\begin{array}{l}\text { US Dollar to national currency spot exchange rate for } \\
\text { the Euro area, US dollar per National Currency Units, } \\
\text { quarterly, not seasonally adjusted }\end{array}$ \\
\hline The UK & $\begin{array}{l}\text { US Dollar to national currency spot exchange rate for the } \\
\text { UK, US Dollar per National Currency Units, quarterly, } \\
\text { not seasonally adjusted }\end{array}$ \\
\hline Exchange Rate US Dollar Growth PostEuro & Growth rate in exchange rate \\
\hline \multicolumn{2}{|l|}{ Credit Nonfinancial } \\
\hline Chile & $\begin{array}{l}\text { Credit to nonfinancial corporations from all sectors at } \\
\text { market value - percentage of GDP-adjusted for breaks }\end{array}$ \\
\hline Colombia & $\begin{array}{l}\text { Credit to nonfinancial corporations from all sectors at } \\
\text { market value-percentage of GDP-adjusted for breaks }\end{array}$ \\
\hline Japan & $\begin{array}{l}\text { Credit to nonfinancial corporations from all sectors at } \\
\text { market value-percentage of GDP_-adjusted for breaks }\end{array}$ \\
\hline Portugal & $\begin{array}{l}\text { Credit to nonfinancial corporations from all sectors at } \\
\text { market value-percentage of GDP_-adjusted for breaks }\end{array}$ \\
\hline The UK & $\begin{array}{l}\text { Credit to nonfinancial corporations from all sectors at } \\
\text { market value-percentage of GDP_-adjusted for breaks }\end{array}$ \\
\hline Credit Nonfinancial Growth & Growth rate in credit to non-financial corporations \\
\hline
\end{tabular}

\section{Quarterly summary statistics}

See Table 10. 
Table 10 Summary statistics for Chile, Colombia, Japan, Portugal and the UK

\begin{tabular}{|c|c|c|c|c|c|}
\hline Variable & Obs & Mean & $\mathrm{SD}$ & Min & Max \\
\hline \multicolumn{6}{|l|}{ Summary statistics } \\
\hline \multicolumn{6}{|l|}{ Chile } \\
\hline exchange rate US dollar growth & 58 & 0.0078667 & 0.1089709 & -0.1950056 & 0.3256963 \\
\hline industrial production growth & 58 & 0.0182668 & 0.0442929 & -0.100076 & 0.1167647 \\
\hline stock market US growth & 58 & 0.1100858 & 0.1708177 & -0.2086939 & 0.4607406 \\
\hline cb policy rate growth & 58 & 0.3674135 & 1.326971 & -0.9393939 & 6.44 \\
\hline credit nonfinancial growth & 58 & 0.0117912 & 0.0873494 & -0.1123321 & 0.2605965 \\
\hline \multicolumn{6}{|l|}{ Colombia } \\
\hline exchange rate US dollar growth & 53 & -0.0026246 & 0.1038676 & -0.2039474 & 0.2601521 \\
\hline industrial production growth & 53 & 0.027104 & 0.0503102 & -0.0982398 & 0.1426854 \\
\hline stock market US growth & 53 & 0.2437501 & 0.4813275 & -0.5568744 & 1.36476 \\
\hline cb policy rate growth & 53 & -0.0007892 & 0.0866519 & -0.2980626 & 0.2325269 \\
\hline credit nonfinancial growth & 53 & 0.011251 & 0.0751425 & -0.1451683 & 0.1475684 \\
\hline \multicolumn{6}{|l|}{ Japan } \\
\hline exchange rate US dollar growth & 90 & 0.0144532 & 0.1160113 & -0.2099815 & 0.2933806 \\
\hline industrial production growth & 82 & 0.0038293 & 0.0796377 & -0.3323831 & 0.2485055 \\
\hline stock market US growth & 90 & 0.0344054 & 0.2258526 & -0.439352 & 0.590337 \\
\hline shadow growth & 90 & -1.306848 & 5.895291 & -51.28868 & 6.831689 \\
\hline credit nonfinancial growth & 90 & -0.0163254 & 0.0289974 & -0.0833943 & 0.05345 \\
\hline \multicolumn{6}{|l|}{ Portugal } \\
\hline exchange rate US dollar growth & 75 & -0.0026406 & 0.1030869 & -0.1992657 & 0.2815318 \\
\hline industrial production growth & 75 & -0.0108857 & 0.0485363 & -0.2036516 & 0.0869367 \\
\hline stock market US growth & 75 & 0.0341661 & 0.2083774 & -0.4834372 & 0.3633739 \\
\hline shadow growth & 75 & -0.3136986 & 1.46416 & -7.21417 & 4.899424 \\
\hline credit nonfinancial growth & 75 & 0.0184447 & 0.0652618 & -0.08726 & 0.1191406 \\
\hline \multicolumn{6}{|l|}{ The UK } \\
\hline exchange rate US dollar growth & 91 & 0.0115163 & 0.0955682 & -0.1388465 & 0.3866806 \\
\hline industrial production growth & 91 & -0.0336491 & 1.715242 & -5.611526 & 6.495533 \\
\hline stock market US growth & 91 & 0.0435241 & 0.1433518 & -0.3402923 & 0.3416169 \\
\hline shadow growth & 91 & -1.269996 & 6.554578 & -48.86209 & 13.98622 \\
\hline credit nonfinancial growth & 91 & 0.0185599 & 0.0519397 & -0.1037838 & 0.1165354 \\
\hline
\end{tabular}

\section{Appendix 3}

\section{Hylleberg, Engle, Granger and Yoo Unit Root Test for the presence of a unit root}

See Table 11. 
Table 11 Results of Hylleberg, Engle, Granger and Yoo Unit Root Tests

Test statistic

$1 \%$ Critical

$5 \%$ Critical

$10 \%$ Critical

Chile

Industrial Production Index

$$
\begin{aligned}
& Z(t)-\operatorname{Fr} 0 \\
& Z(t)-\operatorname{Fr} 1 / 2 \\
& Z(t)-\text { L.Ann } \\
& Z(t)-\text { annual }
\end{aligned}
$$

Joint annual

All frequencies

$\mathrm{CB}$ policy rate

$$
\begin{aligned}
& Z(t)-\operatorname{Fr} 0 \\
& Z(t)-\operatorname{Fr} 1 / 2 \\
& Z(t)-\text { L.Ann } \\
& Z(t)-\text { annual }
\end{aligned}
$$

Joint annual

All frequencies

Credit

$$
\begin{aligned}
& Z(t)-\operatorname{Fr} 0 \\
& Z(t)-\operatorname{Fr} 1 / 2 \\
& Z(t)-\text { L.Ann } \\
& Z(t)-\text { annual }
\end{aligned}
$$

Joint annual

All frequencies

Stock Market Index

$$
\begin{aligned}
& Z(t)-\text { Fr0 } \\
& Z(t)-\text { Fr } 1 / 2 \\
& Z(t)-\text { L.Ann } \\
& Z(t)-\text { annual }
\end{aligned}
$$

Joint annual

All frequencies

Exchange rate

$$
\begin{aligned}
& Z(t)-\text { Fr0 } \\
& Z(t)-\text { Fr } 1 / 2 \\
& Z(t)-\text { L.Ann } \\
& Z(t)-\text { annual }
\end{aligned}
$$

Joint annual

All frequencies

Colombia

Industrial Production Index

$$
\begin{aligned}
& Z(t)-\text { Fr0 } \\
& Z(t)-\text { Fr } 1 / 2 \\
& Z(t)-\text { L.Ann } \\
& Z(t)-\text { annual }
\end{aligned}
$$$$
-3.276
$$

87.535

69.516

$-9.489$

$-5.138$$$
-3.480
$$$$
-2.580
$$$$
-2.570
$$$$
-2.360
$$$$
4.760
$$

$-3.510$

$-2.600$

$-2.530$

$-2.360$

4.730

$-2.890$

$-1.910$

$-1.880$

$-1.680$

3.000

3.380

$-2.870$

$-2.570$

$-1.920$

$-1.590$

$-1.900$

$-1.530$

$-1.660$

$-1.290$

3.120

3.320

2.810

$-2.580$

$-1.540$

$-1.300$

2.350

2.860

$-2.580$

$-1.600$

$-1.540$

$-1.300$

2.350

2.860

$-2.580$

$-1.600$

$-1.540$

$-1.300$

2.350

2.860

$-2.580$

$-1.580$

$-1.530$

$-1.310$

2.360

2.810

$$
\begin{array}{r}
2.570 \\
-1.590 \\
-1.530 \\
-1.290 \\
2.370
\end{array}
$$$$
1.530
$$

$-1.580$

$\begin{array}{lll}-2.530 & -1.880 & -1.530\end{array}$

$\begin{array}{lll}-2.360 & -1.680 & -1.310\end{array}$ 
Table 11 (continued)

\begin{tabular}{|c|c|c|c|c|}
\hline & Test statistic & $1 \%$ Critical & $5 \%$ Critical & $10 \%$ Critical \\
\hline Joint annual & 82.537 & 4.730 & 3.000 & 2.360 \\
\hline All frequencies & 95.854 & . & 3.380 & 2.810 \\
\hline \multicolumn{5}{|l|}{$\mathrm{CB}$ policy rate } \\
\hline$Z(t)-\operatorname{Fr} 0$ & -5.470 & -3.510 & -2.890 & -2.580 \\
\hline$Z(t)-\operatorname{Fr} 1 / 2$ & -5.687 & -2.600 & -1.910 & -1.580 \\
\hline$Z(t)-$ L.Ann & -5.285 & -2.530 & -1.880 & -1.530 \\
\hline$Z(t)-$ annual & -2.870 & -2.360 & -1.680 & -1.310 \\
\hline Joint annual & 20.232 & 4.730 & 3.000 & 2.360 \\
\hline All frequencies & 38.054 & . & 3.380 & 2.810 \\
\hline \multicolumn{5}{|l|}{ Credit } \\
\hline$Z(t)-\operatorname{Fr} 0$ & -3.385 & -3.470 & -2.880 & -2.580 \\
\hline$Z(t)-\operatorname{Fr} 1 / 2$ & -7.851 & -2.610 & -1.950 & -1.600 \\
\hline$Z(t)-$ L.Ann & -1.176 & -2.610 & -1.900 & -1.540 \\
\hline$Z(t)-$ annual & -9.421 & -2.380 & -1.680 & -1.300 \\
\hline Joint annual & 49.205 & 4.770 & 3.080 & 2.350 \\
\hline All frequencies & 43.081 & . & 3.370 & 2.860 \\
\hline \multicolumn{5}{|c|}{ Stock Market Index } \\
\hline$Z(t)-\mathrm{Fr} 0$ & -1.459 & -3.470 & -2.880 & -2.580 \\
\hline$Z(t)-\operatorname{Fr} 1 / 2$ & -5.789 & -2.610 & -1.950 & -1.600 \\
\hline$Z(t)-\mathrm{L} . \mathrm{Ann}$ & -3.034 & -2.610 & -1.900 & -1.540 \\
\hline$Z(t)-$ annual & -5.167 & -2.380 & -1.680 & -1.300 \\
\hline Joint annual & 28.198 & 4.770 & 3.080 & 2.350 \\
\hline All frequencies & 26.377 & . & 3.370 & 2.860 \\
\hline \multicolumn{5}{|l|}{ Exchange rate } \\
\hline$Z(t)-\mathrm{Fr} 0$ & -3.230 & -3.480 & -2.870 & -2.570 \\
\hline$Z(t)-\operatorname{Fr} 1 / 2$ & -9.228 & -2.580 & -1.920 & -1.590 \\
\hline$Z(t)-$ L.Ann & -9.472 & -2.570 & -1.900 & -1.530 \\
\hline$Z(t)-$ annual & -8.391 & -2.360 & -1.660 & -1.290 \\
\hline Joint annual & 130.945 & 4.760 & 3.120 & 2.370 \\
\hline All frequencies & 109.734 & . & 3.320 & 2.810 \\
\hline \multicolumn{5}{|c|}{ Japan } \\
\hline \multicolumn{5}{|c|}{ Industrial Production Index } \\
\hline$Z(t)-\mathrm{Fr} 0$ & -3.852 & -3.480 & -2.870 & -2.570 \\
\hline$Z(t)-\operatorname{Fr} 1 / 2$ & -10.326 & -2.580 & -1.920 & -1.590 \\
\hline$Z(t)-$ L.Ann & -7.351 & -2.570 & -1.900 & -1.530 \\
\hline$Z(t)-$ annual & -15.241 & -2.360 & -1.660 & -1.290 \\
\hline Joint annual & 142.335 & 4.760 & 3.120 & 2.370 \\
\hline All frequencies & 214.902 & . & 3.320 & 2.810 \\
\hline \multicolumn{5}{|l|}{ Shadow rate } \\
\hline$Z(t)-\mathrm{Fr} 0$ & -4.238 & -3.470 & -2.880 & -2.580 \\
\hline$Z(t)-\operatorname{Fr} 1 / 2$ & -4.093 & -2.610 & -1.950 & -1.600 \\
\hline$Z(t)-$ L.Ann & -6.396 & -2.610 & -1.900 & -1.540 \\
\hline
\end{tabular}


Table 11 (continued)

\begin{tabular}{|c|c|c|c|c|}
\hline & Test statistic & $1 \%$ Critical & $5 \%$ Critical & $10 \%$ Critical \\
\hline$Z(t)$ - annual & -1.453 & -2.380 & -1.680 & -1.300 \\
\hline Joint annual & 21.511 & 4.770 & 3.080 & 2.350 \\
\hline All frequencies & 22.737 & . & 3.370 & 2.860 \\
\hline \multicolumn{5}{|l|}{ Credit } \\
\hline$Z(t)-\mathrm{Fr} 0$ & -2.940 & -3.480 & -2.870 & -2.570 \\
\hline$Z(t)-\operatorname{Fr} 1 / 2$ & -11.357 & -2.580 & -1.920 & -1.590 \\
\hline$Z(t)-$ L.Ann & -12.318 & -2.570 & -1.900 & -1.530 \\
\hline$Z(t)-$ annual & -13.223 & -2.360 & -1.660 & -1.290 \\
\hline Joint annual & 162.731 & 4.760 & 3.120 & 2.370 \\
\hline All frequencies & 147.412 & . & 3.320 & 2.810 \\
\hline \multicolumn{5}{|l|}{ Stock Market Index } \\
\hline$Z(t)-\mathrm{Fr} 0$ & -4.284 & -3.480 & -2.870 & -2.570 \\
\hline$Z(t)-\operatorname{Fr} 1 / 2$ & -12.363 & -2.580 & -1.920 & -1.590 \\
\hline$Z(t)-\mathrm{L} . \mathrm{Ann}$ & -8.244 & -2.570 & -1.900 & -1.530 \\
\hline$Z(t)$ - annual & -12.777 & -2.360 & -1.660 & -1.290 \\
\hline Joint annual & 116.592 & 4.760 & 3.120 & 2.370 \\
\hline All frequencies & 180.475 & . & 3.320 & 2.810 \\
\hline \multicolumn{5}{|l|}{ Exchange rate } \\
\hline$Z(t)-\mathrm{Fr} 0$ & -4.888 & -3.480 & -2.870 & -2.570 \\
\hline$Z(t)-\operatorname{Fr} 1 / 2$ & -12.847 & -2.580 & -1.920 & -1.590 \\
\hline$Z(t)-$ L.Ann & -13.248 & -2.570 & -1.900 & -1.530 \\
\hline$Z(t)-$ annual & -8.886 & -2.360 & -1.660 & -1.290 \\
\hline Joint annual & 127.110 & 4.760 & 3.120 & 2.370 \\
\hline All frequencies & 140.904 & . & 3.320 & 2.810 \\
\hline \multicolumn{5}{|l|}{ Portugal } \\
\hline \multicolumn{5}{|c|}{ Industrial Production Index } \\
\hline$Z(t)-\mathrm{Fr} 0$ & -3.814 & -3.480 & -2.870 & -2.570 \\
\hline$Z(t)-\operatorname{Fr} 1 / 2$ & -9.166 & -2.580 & -1.920 & -1.590 \\
\hline$Z(t)-$ L.Ann & -12.302 & -2.570 & -1.900 & -1.530 \\
\hline$Z(t)-$ annual & -7.613 & -2.360 & -1.660 & -1.290 \\
\hline Joint annual & 104.737 & 4.760 & 3.120 & 2.370 \\
\hline All frequencies & 84.295 & . & 3.320 & 2.810 \\
\hline \multicolumn{5}{|l|}{ Shadow rate } \\
\hline$Z(t)-\mathrm{Fr} 0$ & -4.057 & -3.470 & -2.880 & -2.580 \\
\hline$Z(t)-\operatorname{Fr} 1 / 2$ & -4.967 & -2.610 & -1.950 & -1.600 \\
\hline$Z(t)-$ L.Ann & -1.878 & -2.610 & -1.900 & -1.540 \\
\hline$Z(t)-$ annual & -5.434 & -2.380 & -1.680 & -1.300 \\
\hline Joint annual & 16.527 & 4.770 & 3.080 & 2.350 \\
\hline All frequencies & 39.134 & . & 3.370 & 2.860 \\
\hline \multicolumn{5}{|l|}{ Credit } \\
\hline$Z(t)-\mathrm{Fr} 0$ & -2.297 & -3.480 & -2.870 & -2.570 \\
\hline$Z(t)-\operatorname{Fr} 1 / 2$ & -7.323 & -2.580 & -1.920 & -1.590 \\
\hline
\end{tabular}


Table 11 (continued)

\begin{tabular}{|c|c|c|c|c|}
\hline & Test statistic & $1 \%$ Critical & $5 \%$ Critical & $10 \%$ Critical \\
\hline$Z(t)-$ L.Ann & -7.734 & -2.570 & -1.900 & -1.530 \\
\hline$Z(t)-$ annual & -8.180 & -2.360 & -1.660 & -1.290 \\
\hline Joint annual & 63.344 & 4.760 & 3.120 & 2.370 \\
\hline All frequencies & 53.985 & . & 3.320 & 2.810 \\
\hline \multicolumn{5}{|l|}{ Stock Market Index } \\
\hline$Z(t)-\mathrm{Fr} 0$ & -3.233 & -3.510 & -2.890 & -2.580 \\
\hline$Z(t)-\operatorname{Fr} 1 / 2$ & -7.886 & -2.600 & -1.910 & -1.580 \\
\hline$Z(t)-\mathrm{L} . \mathrm{Ann}$ & -5.506 & -2.530 & -1.880 & -1.530 \\
\hline$Z(t)-$ annual & -9.327 & -2.360 & -1.680 & -1.310 \\
\hline Joint annual & 58.954 & 4.730 & 3.000 & 2.360 \\
\hline All frequencies & 93.575 & . & 3.380 & 2.810 \\
\hline \multicolumn{5}{|l|}{ Exchange rate } \\
\hline$Z(t)-\mathrm{Fr} 0$ & -2.505 & -3.470 & -2.880 & -2.580 \\
\hline$Z(t)-\operatorname{Fr} 1 / 2$ & -8.176 & -2.610 & -1.950 & -1.600 \\
\hline$Z(t)-$ L.Ann & -8.444 & -2.610 & -1.900 & -1.540 \\
\hline$Z(t)-$ annual & -5.996 & -2.380 & -1.680 & -1.300 \\
\hline Joint annual & 53.845 & 4.770 & 3.080 & 2.350 \\
\hline All frequencies & 55.291 & . & 3.370 & 2.860 \\
\hline \multicolumn{5}{|l|}{ The UK } \\
\hline \multicolumn{5}{|c|}{ Industrial Production Index } \\
\hline$Z(t)-\mathrm{Fr} 0$ & -8.484 & -3.480 & -2.870 & -2.570 \\
\hline$Z(t)-\operatorname{Fr} 1 / 2$ & -11.691 & -2.580 & -1.920 & -1.590 \\
\hline$Z(t)-$ L.Ann & -20.592 & -2.570 & -1.900 & -1.530 \\
\hline$Z(t)-$ annual & -1.432 & -2.360 & -1.660 & -1.290 \\
\hline Joint annual & 213.023 & 4.760 & 3.120 & 2.370 \\
\hline All frequencies & 198.876 & . & 3.320 & 2.810 \\
\hline \multicolumn{5}{|l|}{ Shadow rate } \\
\hline$Z(t)-\mathrm{Fr} 0$ & -4.682 & -3.470 & -2.880 & -2.580 \\
\hline$Z(t)-\operatorname{Fr} 1 / 2$ & -4.151 & -2.610 & -1.950 & -1.600 \\
\hline$Z(t)-$ L.Ann & -6.587 & -2.610 & -1.900 & -1.540 \\
\hline$Z(t)-$ annual & -1.633 & -2.380 & -1.680 & -1.300 \\
\hline Joint annual & 23.032 & 4.770 & 3.080 & 2.350 \\
\hline All frequencies & 26.258 & . & 3.370 & 2.860 \\
\hline \multicolumn{5}{|l|}{ Credit } \\
\hline$Z(t)-\mathrm{Fr} 0$ & -3.231 & -3.480 & -2.870 & -2.570 \\
\hline$Z(t)-\operatorname{Fr} 1 / 2$ & -9.760 & -2.580 & -1.920 & -1.590 \\
\hline$Z(t)-\mathrm{L} . \mathrm{Ann}$ & -10.216 & -2.570 & -1.900 & -1.530 \\
\hline$Z(t)-$ annual & -8.152 & -2.360 & -1.660 & -1.290 \\
\hline Joint annual & 85.482 & 4.760 & 3.120 & 2.370 \\
\hline All frequencies & 81.539 & . & 3.320 & 2.810 \\
\hline \multicolumn{5}{|l|}{ Stock Market Index } \\
\hline$Z(t)-\mathrm{Fr} 0$ & -4.881 & -3.480 & -2.870 & -2.570 \\
\hline
\end{tabular}


Table 11 (continued)

\begin{tabular}{lcccc}
\hline & Test statistic & $1 \%$ Critical & $5 \%$ Critical & 10\% Critical \\
\hline$Z(t)-$ Fr 1/2 & -12.754 & -2.580 & -1.920 & -1.590 \\
$Z(t)-$ L.Ann & -11.640 & -2.570 & -1.900 & -1.530 \\
$Z(t)-$ annual & -11.318 & -2.360 & -1.660 & -1.290 \\
Joint annual & 131.781 & 4.760 & 3.120 & 2.370 \\
All frequencies & 179.060 &. & 3.320 & 2.810 \\
Exchange rate & & & & \\
$Z(t)-$ Fr0 & -4.244 & -3.480 & -2.870 & -2.570 \\
$Z(t)-$ Fr 1/2 & -12.233 & -2.580 & -1.920 & -1.590 \\
$Z(t)-$ L.Ann & -10.208 & -2.570 & -1.900 & -1.530 \\
$Z(t)$ - annual & -11.215 & -2.360 & -1.660 & -1.290 \\
Joint annual & 114.828 & 4.760 & 3.120 & 2.370 \\
All frequencies & 144.864 & & 3.320 & 2.810 \\
\hline
\end{tabular}

Hylleberg, Engle, Granger and Yoo (HEGY) Test results based on: Ho: Series contains a unit root and Ha: No unit root present. The presence of a unit root is rejected for the cases where the Itest statisticl<|critical valuel. Cases where we fail to reject the null hypothesis of a unit root are highlighted in gray

\section{References}

Afonso, A., and J. Silva. 2017. Effects of Euro Area Monetary Policy on Institutional Sectors: The Case of Portugal. ISEG Economics Department Working Paper No. WP 15/2017/DE/UECE, ISEG: Lisbon.

Afonso, A., and R. Sousa. 2011. The Macroeconomic Effects of Fiscal Policy in Portugal: A Bayesian SVAR Analysis. Portuguese Economic Journal 10(1): 61-82.

Afonso, A., and R. Sousa. 2012. The Macroeconomic Effects of Fiscal Policy. Applied Economics 44(34): 4439-4454.

Allen, F., and D.M. Gale. 2007. An Introduction to Financial Crises. Wharton Financial Institutions Center Working Paper No. 07-20, Wharton Financial Institutions Center: Pennsylvania.

Angelos, K. 2010. A note on the relation between the equity risk premium and the term structure. Journal of Economics and Finance 34(1): 89-95.

Asriyan, V., L. Fornaro, A. Martin, and J. Ventura. 2019. Monetary Policy for a Bubbly World. http:// www.econ.upf.edu/ martin/AFMV.pdf. Accessed 21 March 2020.

Bartov, E., and G.M. Bodnar. 1994a. Firm valuation, earnings expectations, and the exchange rate exposure effect. Journal of Finance 44: 1755-1786.

Bartov, E., and G.M. Bodnar. 1994b. Firm valuation, earnings expectations and the exchange rate exposure effect. Journal of Finance 49(5): 1755-1785.

Bernanke, B.S., and C. Lown. 1991. The credit crunch. Brookings Papers on Economic Activity 22, 205248. https://www.brookings.edu/wp-content/uploads/1991/06/1991b_bpea_bernanke_lown_fried man.pdf. Accessed 21 March 2020.

Borio, C. 2014. Monetary policy and financial stability: What role in prevention and recovery. BIS Working Papers 440, January 2014.

Caglayan, M., K. Mouratidis, and E. Saeidinezhad. 2011. Monetary policy effects on output and exchange rates: Results from US, UK and Japan. Sheffield Economic Research Paper Series 2011016, Department of Economics, University of Sheffield: Sheffield.

Calvo, G., and C. Reinhart. 2000. When capital inflows come to a sudden stop: Consequences and policy options. In Reforming the international monetary and financial system, ed. P. Kenen and A. Swoboda. Washington, D.C: International Monetary Fund.

Catão, L.A.V., and A. Pagan. 2011. The credit channel and monetary transmission in Brazil and Chile: A structural VAR approach. Working Papers Central Bank of Chile 579, Central Bank of Chile. 
Cavallari, L. 2001. Current account and exchange rate dynamics. Economic Notes 30(1): $27-51$.

Cocriş, V., and A.E. Nucu. 2013. Monetary policy and financial stability: empirical evidence from Central and Eastern European countries. Baltic Journal of Economics 13(1): 75-98.

Clarida, R., and J. Galí. 1994. Sources of real exchange rate fluctuations: How important are nominal shocks? Carnegie Rochester Conference Series on Public Policy 41: 1-56.

Crockett, A.D. 1997. Why is financial stability a goal of public policy. Economic Review 82: 5-22.

Dhrymes, P.J., and T.D. Dimitrios. 1997. Structural VAR, MARMA and Open Economy Models. Columbia University Discussion Paper 9798-07, Columbia, New York. https://core.ac.uk/download/ pdf/161436576.pdf. Accessed 21 March 2020.

Drehmann, M., C. Borio, and K. Tsatsaronis. 2011. Anchoring countercyclical capital buffers: The role of credit aggregates. BIS Working Papers 355, November 2011, Bank for International Settlements: Basel, Switzerland.

Eichenbaum, M., and C. Evans. 1995. Some empirical evidence on the effects of monetary policy shocks on exchange rates. Quarterly Journal of Economics 110: 975-1009.

Eichengreen, B., and P. Gupta. 2015. Tapering talk: The impact of expectations of reduced Federal Reserve security purchases on emerging markets. Emerging Markets Review 25: 1-15.

Elbourne, A. 2008. The UK housing market and the monetary policy transmission mechanism: An SVAR approach. Journal of Housing Economics 17: 65-87. https://doi.org/10.1016/j.jhe.2007.09.002.

Fama, E. 1981. Stock returns, real activity, inflation, and money. The American Economic Review 71(4): $545-565$.

Faust, J., and J. Rogers. 2003. Monetary policy's role in exchange rate behaviour. Journal of Monetary Economics 2003: 1-54.

Geske, R., and R. Roll. 1983. The fiscal and monetary linkage between stock returns and inflation. The Journal of Finance 38(1): 1-33.

Gourinchas, P.O., and M. Obstfeld. 2012. Stories of the twentieth century for the twenty-first. American Economic Journal: Macroeconomics 4(1): 226-265.

Granville, B., and S. Mallick. 2009. Monetary and financial stability in the euro area: Pro cyclicality versus trade-off. Journal of International Financial Markets, Institutions and Money 19(4): 662-674.

Grilli, V., and N. Roubini. 1996. Liquidity models in open economies: Theory and empirical evidence. European Economic Review 40: 847-859.

Hacker, R.S., H.K. Karlsson, and K. Månsson. 2012. The relationship between exchange rates and interest rate differentials: A wavelet approach. World Econ 35(9): 1162-1185.

Hurwicz, L. 1962. On the structural form of interdependent systems. In Logic, Methodology and Philosophy of Science, 232-239. Stanford University Press: Stanford, CA.

Inoue, A., and B. Rossi. 2019. The effects of conventional and unconventional monetary policy on exchange rates. Journal of International Economics 118(2019): 419-447.

Ivanov, V., and L. Kilian. 2001. A practioner's guide to lag-order selection for vector autorgressions. CEPR Discussion Papers 2685, C.E.P.R. Discussion Papers, Centre for Economic Policy Research: London.

Jiménez, G., S. Ongena, J.L. Peydró, and J. Saurina. 2012. Credit supply and monetary policy: Identifying the bank balance-sheet channel with loan applications. American Economic Review 102(5): 2301-2326.

Jordà, O., M. Schularick, and A. Taylor. 2011. Financial crises, credit booms, and external imbalances: 140 years of lessons. IMF Economic Review 59(2): 340-378.

Jordà, O., M. Schularick, and A.M. Taylor. 2013. When credit bites back. Journal of Money, Credit and Banking 45(s2): 3-28.

Kim, S. 2001. International transmission of US monetary policy shocks: Evidence from VAR's. Journal of Monetary Economics 48(2): 339-372.

Kim, K. 2003. Dollar exchange rate and stock price: Evidence from multivariate cointegration and error correction model. Review of Financial Economics 12(301): 313.

Kim, S., and N. Roubini. 2000. Exchange rate anomalies in the industrial countries: A solution with a structural VAR approach. Journal of Monetary Economics 45(3): 561-586.

Krippner, Leo. 2013. Measuring the stance of monetary policy in zero lower bound environments. Economics Letters 118: 135-138.

Krippner, L. 2015. Zero lower bound term structure modelling: A practitioner's guide. London: Palgrave-Macmillan. 
Kryvstov, O., M. Molico, and B. Tomlin. 2015. On the nexus of monetary policy and financial stability: Recent developments and research. Bank of Canada Discussion Paper 2015-7: Bank of Canada, Ottawa.

Lee, J., and M. Chinn. 2002. Current account and the real exchange rate dynamics in the G-7 countries. IMF Working Paper WP/02/130: Washington, D.C.

Litterman, R.B. 1979. Techniques of forecasting using vector autoregressions. Federal Reserve Bank of Minneapolis Working Paper 115, Federal Reserve Bank of Minneapolis: Minnesota, U.S.

Najand, M., and G. Noronha. 1998. Causal relations among stock returns, inflation, real activity, and interest rates: Evidence from Japan. Global Finance Journal 9(1): 71-80.

Nakahira, K. 2009. A structural VAR analysis of the monetary policy stance in Japan. The International Journal of Economic Policy Studies 4(5): 77-103.

Ouhibi, S., and S. Hammami. 2015. Determinants of non-performing loans in the southern mediterranean countries. International Journal of Accounting and Economic Studies 3(1): 50-53.

Park, D., A. Ramayandi, and K. Shin. 2016. Capital flows during quantitative easing and aftermath: Experiences of Asian countries. Emerging Markets Finance \& Trade 52(4): 886-903.

Parrado, E. 2001. Effects of foreign and domestic monetary policy in a small open economy: The Case of Chile. Central Bank of Chile Working Papers 108, Central Bank of Chile: Huérfanos.

Restrepo, J.E., and H. Rincon. 2006. Identifying fiscal policy shocks in Chile and Colombia. http://ssrn. com/abstract=2005164. Accessed 4 April 2020.

Robinson, J. 1952. The generalisation of the general theory. In the rate of interest, and other essays, vol. 2. London: Macmillan.

Schenck, D. 2016. Structural vector autoregression models. The STATA Blog, 20 September 2016. https ://blog.stata.com/2016/09/20/structural-vectorautoregression-models/. Accessed 5 August 2019.

Schenkelberg, H., and S. Watzka. 2013. Real effects of quantitative easing at the zero lower bound: Structural VAR-based evidence from Japan. Journal of International Money and Finance 33: 327-357.

Schularick, M., and A. Taylor. 2012. Credit booms gone bust: Monetary policy, leverage cycles, and financial crises: 1870-2008. American Economic Review 102: 1029-1061.

Sims, C.A. 1980. Macroeconomics and reality. Econometrica 48(1): 1-48.

Sims, C.A. 2002. Structural VAR's. Econ. 513, Time Series Econometrics, Fall 2002. https:// uh.edu/ bsorense/SimsVARS.pdf. Accessed 22 March 2020.

Sousa, R.M. 2014. The effects of monetary policy in a small open economy: the case of Portugal. Applied Economics 46(2): 240-251.

Yang, S.Y., and S.C. Doong. 2004. Price and volatility spillovers between stock prices and exchange rates: Empirical evidence from the G-7 countries. International Journal of Business and Economics 3(2): 139-153.

Yanoy, K., and N. Yoshinoz. 2009. Japanese monetary policy reaction function and time varying structural vector autoregressions: A Monte Carlo particle filtering approach. https://pdfs.semanticsc holar.org/2595/b8e647256f4e28d2df7c02cfce0f961b8323.pdf_ga=2.265536966.898582935.15860 39441-563876310.1586039441. Accessed 4 April 2020.

Publisher's Note Springer Nature remains neutral with regard to jurisdictional claims in published maps and institutional affiliations. 